\title{
Soil Nitrogen Levels in a Semiarid Climate Following Long-term Nitrogen Fertilization
}

\section{FORREST A. SNEVA}

Highlight: Fertilizing crested wheatgrass for 14 years with 34 $\mathrm{kg} / \mathrm{ha}$ or less did not significantly increase the $\mathrm{NO}_{3}-\mathrm{N}$ concentration in a semiarid soil. Fertilization rates of $56 \mathrm{~kg} / \mathrm{ha}$ or more resulted in a significant accumulation of $\mathrm{NO}_{3}-\mathrm{N}$ just above the cemented caliche layer. Total $N$ accumulation in the upper $61 \mathrm{~cm}$ of soil from $N$ fertilization levels of less than $56 \mathrm{~kg} / \mathrm{ha}$ did not exceed $30 \%$ of that normally occurring in the profile.

Nitrogen $(\mathrm{N})$ fertilization of semiarid soil to increase forage production is neither widely recommended nor extensively practiced. For this reason, on- or off-site pollution effects have not been of major concern to investigators. However, grazing use of our natural resource lands is being reduced by land withdrawals, urban sprawl, and administrative edict. Concurrently the cattle industry is attempting to increase the proportion of grass-fat beef in the market. Thus, despite rising fertilizer cost, its use depends upon fat cattle prices as it is influenced by fed gra in prices.

This paper documents residual amounts of total $\mathrm{N}, \mathrm{NH}_{4}-\mathrm{N}$ and $\mathrm{NO}$ - $-\mathrm{N}$ remaining in the soil following 14 years of fertilizing a stand of crested wheatgrass (Agropyron desertorum (Fisch ex Link) Schult.) with several levels of ammonium nitrate.

\section{Materials and Methods}

The Squaw Butte Experiment Station is located in southeastern Oregon, at an elevation of 1,371 meters. It receives approximately 30 $\mathrm{cm}$ of precipitation annually, mostly as rain or snow during the winter months.

The soil at the study site is unclassified, but has been described by Eckert (1957) as sandy loams overlying variable sandy-clay-loams to a depth of $48-81 \mathrm{~cm}$. At the study site, the caliche layer began at approximately $61 \mathrm{~cm}$ below the soil surface.

In the spring of 1956, plots (about $3 \times 4 \mathrm{~m}$ ) were seeded to crested wheatgrass in rows spaced $30 \mathrm{~cm}$ apart. Five levels of ammonium nitrate $(0,22,34,56$, and $90 \mathrm{~kg}$ of $\mathrm{N} / \mathrm{ha}$ ) were broadcast on those plots in the fall of each year from 1956 through 1971, with the exception of 1966 and 1969, when no fertilizer was applied.

Soil samples were collected in April, 1973, from soil depths of approximately 0 to 20,21 to 41 , and 42 to $61 \mathrm{~cm}$. An impervious caliche layer limits water movement below this depth. Samples were air dried, screened, and subsequently analyzed for total $\mathrm{N}, \mathrm{NO}_{3}-\mathrm{N}$ and $\mathrm{NH}_{4}-\mathrm{N}$ (A.O.A.C. 1965). Total $\mathrm{N}$ was measured as Kjeldahl-N, $\mathrm{NH}_{4}-\mathrm{N}$ was obtained by steam distillation in the presence of formic

The author is range scientist, U.S. Department of Agriculture, Agricultural Research Service.

The report represents the cooperative investigations of the U.S. Department of Agriculture, Agricultural Research Service, and Oregon Agricultural Experiment Station, Squaw Butte Experiment Station, Burns, Oregon, OAES Technical Paper No. 4248.

Manuscript received August 21, 1976. acid, and $\mathrm{NO}_{3}-\mathrm{N}$ was extracted by $\mathrm{MgO}$ in the presence of Devardas alloy.

In April of 1974, soil cores by $20.3 \mathrm{~cm}$ increments were taken to a $61 \mathrm{~cm}$ depth from unfertilized plots and from plots fertilized with $90 \mathrm{~kg}$ $\mathrm{N} / \mathrm{ha}$. These cores were used to establish bulk density.

During 1957-1966, and in 1971 and 1972, forage was sampled on May 15 and herbage yield and $\mathrm{N}$ concentrations were determined. Following the spring sampling the remaining grass growth on the plot was mowed but not removed. Then, on August 1, the regrowth was sampled and yield and $\mathrm{N}$ concentration again determined. During the years 1967-1970, no direct yield estimates were made. For these years yield estimates were extrapolated from yield and $\mathrm{N}$ data of crested wheatgrass plots in an adjacent study, where harvest dates and some fertilizer treatments were the same.

Statistically, the study was a randomized block design with three replications.

\section{Results}

Total $\mathrm{N}$ decreased significantly $(P<0.05)$ with each successive increment in soil depth (Table 1 ). Fertilizer rates of 22, 56, and $90 \mathrm{~kg} / \mathrm{ha}$ caused a significant $(P<0.05)$ increase in total $\mathrm{N}$ above that of control plots, but $\mathrm{N}$ differences among those rates were not significant. Thirty-four $\mathrm{kg} \mathrm{N} / \mathrm{ha}$ did not significantly $(P>0.05)$ increase total $\mathrm{N}$ above that of control plots.

Table 1. Total $\mathbf{N}$ concentration (\%) in the soil as influenced by soil depth and rates of $\mathbf{N}$ fertilization.

\begin{tabular}{lcccccc}
\hline & \multicolumn{5}{c}{ Fertilizer rate (kg N/ha) } \\
\cline { 3 - 7 } Depth (cm) & 0 & 22 & 34 & 56 & 90 & Mean \\
\hline 0 to 20 & .048 & .057 & .056 & .061 & .063 & $.057^{a}$ \\
21 to 41 & .042 & .049 & .043 & .049 & .055 & $.048^{b}$ \\
42 to 61 & .039 & .045 & .038 & .043 & .049 & $.043^{c}$ \\
Mean & $.043^{a}$ & $.051^{b}$ & $.045^{a}$ & $.051^{b}$ & $.056^{b}$ & \\
\hline
\end{tabular}

$a, b, c$ Statistical difference between means denoted by unlike letters $(P<0.05)$.

Nitrate-N and $\mathrm{NH}_{4}-\mathrm{N}$ concentrations significantly $(P<0.05)$ interacted with fertilization rate and soil depth (Fig. 1). Nitrate$\mathrm{N}$ concentrations from fertilization levels of $34 \mathrm{~kg} / \mathrm{ha}$ or were less than $6 \mathrm{ppm}$ at all soil depths. Nitrate-N concentrations increased with depth to 22 and $61 \mathrm{ppm}$ in the 42 to $61 \mathrm{~cm}$ soil depth for the 56 and $90 \mathrm{~kg} \mathrm{~N} / \mathrm{ha}$ rate, respectively.

Ammonium-N concentrations in the upper $20 \mathrm{~cm}$ of soil increased from approximately $9 \mathrm{ppm}$ on control plots to $73 \mathrm{ppm}$ with $90 \mathrm{~kg} \mathrm{~N} / \mathrm{ha}$ (Fig. 1). These amounts declined to less than 25 ppm in the 21 to $41 \mathrm{~cm}$ depth and below $13 \mathrm{ppm}$ in the lower 41 to $61 \mathrm{~cm}$ depth. 

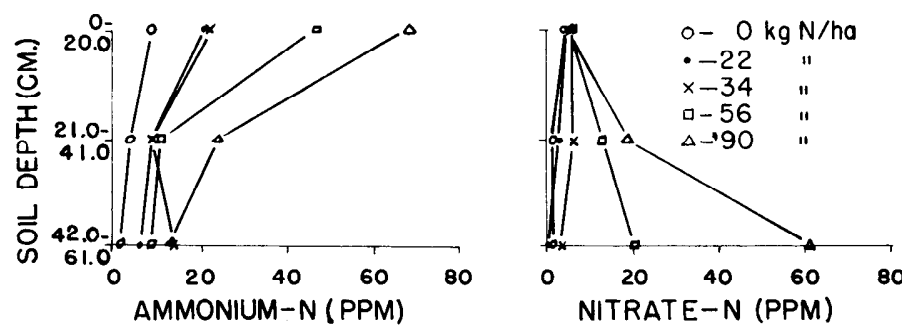

Fig. 1. Ammonium- $N$ and nitrate- $N$ accumulations in a semiarid soil following long-term nitrogen fertilization.

Soil bulk density was unaffected by $\mathrm{N}$ rate, but did significantly $(P<0.05)$ incrcase as soil depth increased. Mean values for the 0-20, 21-41, 42-61 cm increments were $1.26,1.32$, and $1.35 \mathrm{~g} / \mathrm{cc}$, respectively.

Based upon the soil bulk density and total $\mathrm{N}$ analysis the total soil $\mathrm{N}$ yield of unfertilized plots was $1,237,1,118$, and 1,070 $\mathrm{kg} / \mathrm{ha}$ for $0-20,41-61$, and $42-61 \mathrm{~cm}$ increments. The greatest increase in residual total $\mathrm{N}$ occurred in the upper $20 \mathrm{~cm}$ of soil at the 56 and $90 \mathrm{~kg} / \mathrm{ha}$ fertilization rates and in the $21-41 \mathrm{~cm}$ increment at the $90 \mathrm{~kg} / \mathrm{ha}$ rate (Table 2). A decrease in residual amount occurred at the 42 to $61 \mathrm{~cm}$ depth on plots fertilized at the $34 \mathrm{~kg} / \mathrm{ha}$ rate. For the total $61 \mathrm{~cm}$ of soil, the least amount of residual total $\mathrm{N}$ was measured from the $34 \mathrm{~kg} / \mathrm{ha}$ rate. The residual amounts of total $\mathrm{N}$ for the $61 \mathrm{~cm}$ of soil sampled represent increases of $15,6,18$, and $29 \%$ above the check plot yield, respectively, for $22,34,56$, and $90 \mathrm{~kg} \mathrm{~N} / \mathrm{ha}$.

Table 2. Changes in the $\mathrm{N}$-content of the upper $61 \mathrm{~cm}$ of soil from 14 years of fertilization with 4 levels of $N$.

\begin{tabular}{lccccc}
\hline & Total N & \multicolumn{4}{c}{ N applied annually $(\mathrm{kg} / \mathrm{ha})$} \\
\cline { 3 - 6 } Soil depth $(\mathrm{cm})$ & in control plots & 22 & 34 & 56 & 90 \\
\hline 0 to 20 & 1,237 & +146 & +197 & +317 & +376 \\
21 to 41 & 1,118 & +204 & +27 & +196 & +357 \\
42 to 61 & 1,070 & +164 & -28 & +110 & +266 \\
Total & 3,425 & +514 & +196 & +623 & +999 \\
\hline
\end{tabular}

Total soil nitrogen, $\mathrm{N}$ additions and withdrawals, and final $\mathrm{N}$ accounting for the study is presented in Figure 2. Nitrogen addition to the soil, in addition to the fertilizer applied, consisted of that received via precipitation and was estimated at $2.2 \mathrm{~kg} \mathrm{~N} /$ ha per year. Recovery of applied fertilizer $\mathrm{N}$ through the herbage was $30,26,21$, and $23 \%$, respectively, for $\mathrm{N}$

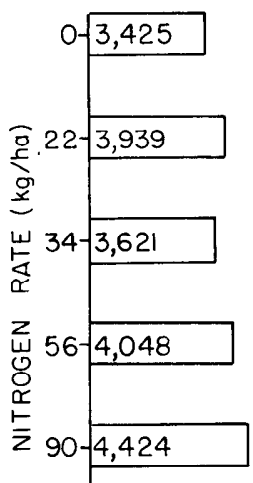

TOTAL $-\mathrm{N}$

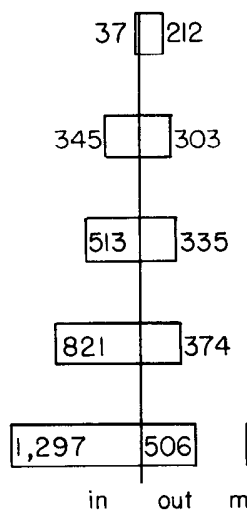

N-FLOW

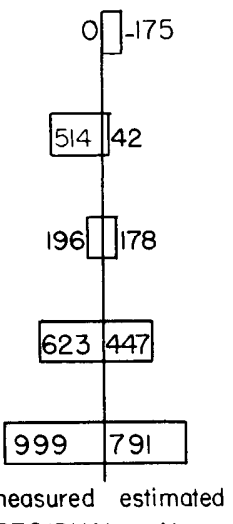

RESIDUAL - N

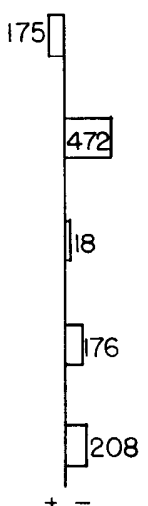

NET DIFF.
Fig. 2. Total soil nitrogen $(\mathrm{kg} / \mathrm{ha})$, nitrogen additions and withdrawals $(\mathrm{kg} /$ ha), measured and estimated residual nitrogen ( $\mathrm{kg} / \mathrm{ha}$ ) and net differences in accountability ( $\mathrm{kg} / \mathrm{ha}$ ) on a semiarid soil followng long-term nitrogen fertilization. fertilization rates of $22,34,56$, and $90 \mathrm{~kg} / \mathrm{ha}$. Measured residual soil $\mathrm{N}$ exceeded estimated residual $\mathrm{N}$ at all rates of applied $\mathrm{N}$.

\section{Discussion}

Residual NO3-N was significantly increased in the lower depth of this soil only when fertilizer rate exceeded $34 \mathrm{~kg} / \mathrm{ha}$. Sneva et al. (1958) and Long and Landers (1968) concluded that a fertilizer level of less than $34 \mathrm{~kg} \mathrm{~N} / \mathrm{ha}$ was the most efficient for crested wheatgrass production in eastern Oregon and Wyoming, respectively. Thus, no residual $\mathrm{NO}_{3}-\mathrm{N}$ should accumulate in these soils if this recommended rate is used. These results are in agreement with those reported by Sommerfeldt and Smith (1973), Larson et al. (1971), Power (1970), and Power et al. (1973), who studied the grassland and cultivated soils of the Northern Great Plains.

The buildup of NO:3- $\mathrm{N}$ in the deeper depths from nitrogen fertilization in excess of $34 \mathrm{~kg} / \mathrm{ha}$ suggested that the $\mathrm{N}$-pool has been saturated. Deep drainage or seepage in these soils is unlikely because precipitation is too limited to accomplish leaching, and the presence of an impervious layer would prevent it. Thus, a single, high $\mathrm{N}$ application should provide an excess of NO:3-N that would be retained with only a small loss from the system. The disadvantages of a single high $\mathrm{N}$ application would be the accumulation of $\mathrm{NO}: \mathrm{N}$ at a depth below the primary rooting zone, which would be an inefficient means of maintaining an adequate supply of $\mathrm{N}$ to the plant. There is also a possibility of denitrification whenever an excess of NO3-N accumulates.

Clark (1924) suggested that 5.6 to $7.8 \mathrm{~kg} \mathrm{~N} / \mathrm{ha}$ was added via precipitation in temperate regions. Recent investigations by Tarrant, et al. (1967), Lodge et al. (1968), Hart et al. (1971), and Fredrikson (1972) suggested much lower $\mathrm{N}$ additions via precipitation for the Pacific Northwest and Intermountain areas. Although no measurements were taken, the value of $2.2 \mathrm{~kg} \mathrm{~N} / \mathrm{ha}$ was chosen for use in this report, based upon research cited.

On plots receiving no fertilizer the amount of $\mathrm{N}$ removed through the harvested forage was $212 \mathrm{~kg} / \mathrm{ha}$, approximately 5 to 6 times the amount of $\mathrm{N}$ estimated as received through precipitation additions ( $37 \mathrm{~kg} / \mathrm{ha})$. However, the estimate of $\mathrm{N}$ removed in the forage is derived from herbage harvested in the spring and again after summer regrowth. Sneva et al. (1958) reported N yields in crested wheatgrass harvested on June 1 to be nearly twice that in mature grass harvested on August 1. Over a 13-year period, crested wheatgrass yields harvested on August 1 contained an average of $5.6 \mathrm{~kg} \mathrm{~N} / \mathrm{ha}$ (Sneva 1973). Thus, harvesting crested wheatgrass in a mature stage from unfertilized areas removed 2.5 times the amount of $\mathrm{N}$ as is received through precipitation (as estimated herein), while harvesting earlier will remove greater amounts of $\mathrm{N}$.

Differences in the total $\mathrm{N}$ unaccounted for in Figure 2 between $\mathrm{N}$ rates are not likely to be significant in themselves, with the possible exception of the $22 \mathrm{~kg} / \mathrm{ha}$ rate. Considering that the total $\mathrm{N}$ supply in the upper $61 \mathrm{~cm}$ of this soil approximates $3,400 \mathrm{~kg}$, these unaccountable $\mathrm{N}$ amounts represent 5 , $14,1,5$, and $6 \%$ of that base amount, respectively, for the 0,22 , 34,56 , and $90 \mathrm{~kg} / \mathrm{ha}$ fertilization rates. Even the $14 \%$ figure is not large relative to the normal errors associated with these kinds of samples. Thus, one could conclude that the accountability of applied $\mathrm{N}$ has been quite good.

At all fertilization rates, the unaccountable amounts of $\mathrm{N}$ indicated a positive balance. Nitrogen addition to the system could have resulted from recycled herbage $\mathrm{N}$ from the spring 
harvest. While the sampled herbage was removed from the area, the remaining grass in the treatment area was closely mowed but retained on that area. Other additions of $\mathrm{N}$ could have come by mineralization of soil organic matter, plant adsorption of atmospheric ammonia- $\mathrm{N}$, and biological- $\mathrm{N}$ fixation.

The $472 \mathrm{~kg} \mathrm{~N} / \mathrm{ha}$ unaccounted for at the $22 \mathrm{~kg} / \mathrm{ha}$ fertilization rate is not large when compared to the soil $\mathrm{N}$ base of 3,400 $\mathrm{kg} / \mathrm{ha}$. It contrasts sharply, however, with the $\mathrm{N}$ amounts remaining at the other nitrogen fertilization rates. This contrast, particularly that between the 22 and $34 \mathrm{~kg} / \mathrm{ha}$ rates, interests the writer because of previous discrepancies in response between these two fertilizer rates. In the 10 years of herbage yield sampling on these plots, $22 \mathrm{~kg}$ of N/ha caused greater yield in 8 years than the $34 \mathrm{~kg} / \mathrm{ha}$ rate (Sneva and Rittenhouse 1976). In none of those years, nor in the means of the 10 years, were yield differences significant $(P>0.05)$. Yet, increasing levels of $\mathrm{N}$ above $34 \mathrm{~kg} / \mathrm{ha}$ did cause significant yield increases in some years. Discrete differences due to fertilizer level were evident in herbage crude protein and dry matter concentrations, yet soil moisture depletion curves were sometimes reversed. Thus, the inconsistency seen in the residual amounts of total in this study at the 22 and $34 \mathrm{~kg} / \mathrm{ha}$ fertilization rates is not inconsistent with previous response fluctuations measured.

It is possible that this discrepancy is real. Three explanations are offered. First, during the years 1971 and 1972, yield response to $\mathrm{N}$ was being limited by the availability of sulfur (Sneva and Rittenhouse 1976). Li (1964) and Williams (1967) have reported on the impact of soil temperature on soil sulfur mobilization. Thus nitrogen fertilization rate, availability of sulfur, and early spring temperature interactions may explain the discrepancy.

Second, competition for applied $\mathrm{N}$ between root systems and the microbial populations on these low organic matter, semiarid soils may also interfere with the plant response to $\mathrm{N}$. Thus, between the 22 and the $34 \mathrm{~kg} / \mathrm{h}$ a rates, we may be encountering a sensitive, biological threshold that may account for the discrepancy.

Third, rather than being tied up by competitive forces, applied nitrogen can stimulate the production of microbial populations and increase the output of $\mathrm{N}$ from a system. This "priming effect" has been recently studied and discussed by Westerman and Kurtz (1973).

If the estimate of $2.2 \mathrm{~kg} / \mathrm{ha}$ added annually via precipitation is approximately correct, then the removal of $13.2 \mathrm{~kg} / \mathrm{ha}$ annually by crested wheatgrass suggests that a depletion of $11.0 \mathrm{~kg} / \mathrm{ha}$ is occurring annually. Because a yield response to $\mathrm{N}$ fertilizer occurs on these soils, it is generally assumed that such grasses deplete soil N. However, declining herbage yield over time occurred both on fertilized and unfertilized plots of this study (Sneva and Rittenhouse 1976). Thus, it is inferred that the 11.0 $\mathrm{kg} / \mathrm{ha}$ may be an estimation of unknown $\mathrm{N}$ additions, rather than a depletion of soil $\mathrm{N}$.

Most importantly, this study reveals that, should $\mathrm{N}$ fertilization of crested wheatgrass on semiarid soils become a practice, there is no danger of on- or off-side $\mathrm{NO}_{3}-\mathrm{N}$ pollution when the recommended rates of $\mathrm{N}$ are used.

\section{Literature Cited}

A.O.A.C. 1965. Official methods of analysis of Ass. Offic. Agr. Chem., Washington, D.C.

Clark, Frank W. 1924. The data of geochemistry. 5th Ed. U.S. Dep. Interior, Geol. Survey, Bull. 770. 841 p.

Eckert, R. E., Jr. 1957. Vegetation-soil relationships in some Artemisia types in Northern Harney and Lake counties, Oregon. PhD Thesis. Oregon State Univ., Corvallis. 208 p.

Fredrikson, R. L. 1972. Nutrient budget of a Douglas fir forest on an experimental watershed in Western Oregon. In: Proc. Research on Coniferous Forest Ecosystems. p. 115-131. Billingham, Wash. Mar. 23-34. Pacific Northwest Forest and Range Exp. Sta., Portland, Ore.

Hart, George, E., A. R. Southard, and J. S. Williams. 1971. Chemistry of precipitation and stream flow in north central Utah. Amer. Geophys. Union Proc. Mimeo. 6 p. San Francisco, Calif.

Lang, Robert, and L. Landers. 1968. Nitrogen fertilization of crested wheatgrass in northeastem Wyoming. Univ. of Wyoming Agr. Exp. Sta. Res. J. 21. $20 \mathrm{p}$.

Larson, K. L., J. F. Canter, and E. N. Vasey. 1971. Nitrate-nitrogen acculation under bromegrass soil fertilized annually at six levels of nitrogen for fifteen year. Agron. J. 63:527-528.

Li, Pauline. Y. W. 1964. The oxidation of elemental sulfur in soils. MS Thesis, Univ. of Minnesota, St. Paul. 198 p.

Lodge, J. P., Jr., J. B. Pate, W. Basbergill, G. S. Swanson, K. C. Hill, E. Lorange, and A. L. Lazrus. 1968. Chemistry of United States precipitation. Nat. Center for Atmos. Res., Boulder, Colo. 66 p.

Power, J. F. 1970. Leaching of nitrate-nitrogen under dryland agriculture in the Northern Great Plains. In: Relationship of Agriculture to Soil and Water Pollution. Cornell Univ. Press, Ithaca, N.Y.

Power, J. F., J. Alessi, G. A. Reichman, and D. L. Grunes. 1973. Recovery, residual effects, and fate of nitrogen fertilizer sources in a semi-arid region. Agron. J. 65:765-768.

Sneva, Forrest A. 1973. Crested wheatgrass response to nitrogen and clipping. J. Range Manage. 26:47-50.

Sneva, Forrest A., D. N. Hyder, and C. S. Cooper. 1958. The influence of ammonium nitrate on the growth yield of crested wheatgrass on the Oregon high desert. Agron. J. Vol. 40-44

Sneva, Forrest A., and L. R. Rittenhouse. 1976. Crested wheatgrass production: Fertility, row spacing, and stand age impacts. Oregon State Univ. Agr. Exp. Sta. Tech. Bull. 131. In Press.

Sommerfeldt, Theron, G., and A. D. Smith. 1973. Movement of nitrate nitrogen in some grassland soils of southern Alberta. J. Environ. Qua. 2:112-115.

Terrant, R. F., K. C. Lu, C. S. Chen, and W. B. Bollen. 1968. Nitrogen content of precipitation in a coastal forest opening. Tellus XX, 3 p. 554-556.

Westerman, R. L., and L. T. Kuntz. 1973. Priming effect of ${ }^{15}$-labeled fertilizers on soil nitrogen in field experiments. Soil Sci. Soc. Amer. Proc. 37:725-727.

Williams, C. N. 1967. Some factors affecting the mineralization of organic sulfur in soils. Plant and Soils 26:205-222.

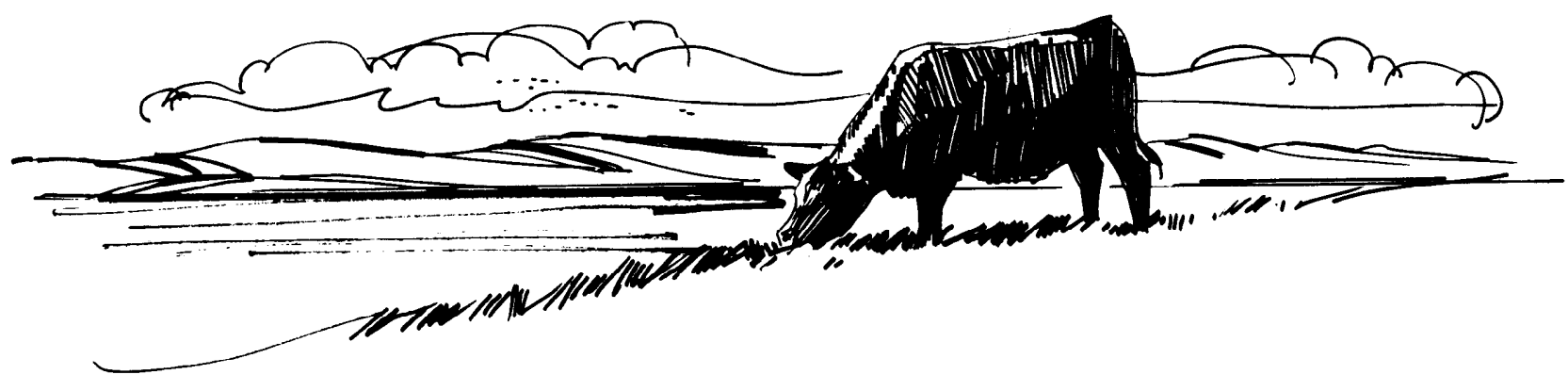

